open 2 access

\title{
Impact Evaluation of Healthy City Implementation in Makassar City
}

\author{
Inayyah Nur Fitry ${ }^{1}$, Sukri Palutturi ${ }^{1 *}$, Ridwan M. Thaha ${ }^{2}$, Aminuddin Syam $^{3}$ \\ ${ }^{1}$ Department of Health Administration and Policy, Faculty of Public Health, Hasanuddin University, Makassar, Indonesia; \\ ${ }^{2}$ Department of Health Promotion and Behavioral Sciences, Faculty of Public Health, Hasanuddin University, Makassar, \\ Indonesia; ${ }^{3}$ Department of Nutrition Science, Faculty of Public Health, Hasanuddin University, Makassar, Indonesia
}

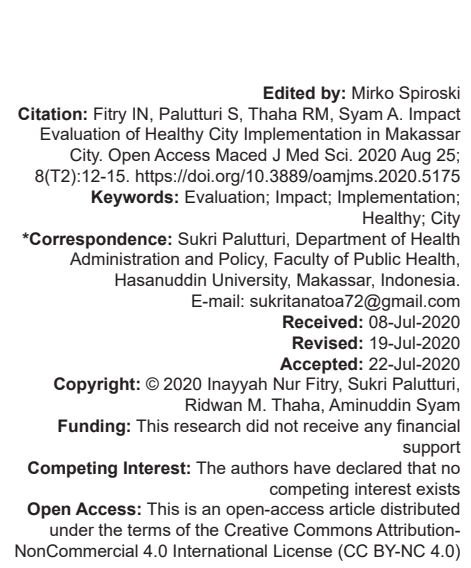

\section{Introduction}

Cities play an important role in the social fabric of the country and national and regional economies throughout the world. In theory and public opinion, the city offers opportunities for education, employment, services, and cultural enrichment and hopes for better health. In fact, these opportunities may not be as busy as expected [1].

The city growth that is high enough to have an impact in various fields of life is not only limited to physical problems but also in the economic, social, cultural, political, and health fields. City as an urban living environment can grow and develop through two changes that are internally or externally [2].

Makassar is one of the most populous cities in Indonesia. Population density in Makassar makes this city inseparable from various urban problems that occur today.

In an effort to overcome these urban problems, the World Health Organization (WHO) in the 1980 introduced a concept that was considered a comprehensive approach aimed at facilitating and creating a healthier urban environment. The concept is healthy city [3].

The concept of a healthy city is an old and new concept. Old means that humans have been trying to make cities healthier since the beginning of urban [4].

A healthy city is a condition of a city that is clean, comfortable, safe, and healthy for residents to live in. The implementation is achieved through the application of several arrangements with integrated activities agreed by the community and local government. Organizing a healthy city is a variety of activities to realize a healthy city, through community empowerment, and a forum facilitated by the city government [5].

Regulations regarding the administration of healthy cities in Indonesia are regulated through Joint Regulation of the Minister of Home Affairs and the Minister of Health Number 34 of 2005 and Number 1138/ Menkes/PB/VIII/2005 on August 3, 2005, concerning the implementation of healthy regencies/cities. The program for the realization of a healthy city in Makassar has been started since 2007. In Makassar, a healthy cities forum has been formed which serves as an 
institution that facilitates the realization of the healthy cities program. Makassar city has won the Swasti Saba Wistara award 4 times in a row [6].

However, the implementation of a healthy city in Makassar is still not as smooth as imagined. The concept of a healthy city in Makassar still needs to be further evaluated. One way to determine the problem of implementing a program can be done by evaluating the program, the application process, or at the end of the application. Evaluation of a program or policy needs to be done to answer whether differences have been made from the implementation of a program [7].

The importance of identifying evaluations of the impact of interventions has been emphasized WHO. In preparation for and during the 1998 evaluation meeting, healthy city project evaluation documents were considered [8], [9]. Meanwhile, according to Tahalea et al. [10] said that an evaluation of the impact on a program or policy is carried out to assess individual impacts, organizational impacts, and impacts on the social system.

The WHO [11] states that one of the impacts of healthy city implementation is the degree of involvement. The impact consists of two indicators, namely, women's involvement and political commitment. Therefore, this study was conducted to evaluate the impact of the implementation of a healthy city in Makassar since its application in 2007.

\section{Materials and Methods}

This research was conducted in Makassar city as one of the cities that have consistently carried out a healthy city program since 2007 . The time of the study was conducted from March 22, 2018 to May 1, 2019.

There were 13 informants in the study which consist of the Makassar Deputy Mayor, Healthy City Forum Chairperson of Makassar, Head of SocioCultural Affairs of Bappeda Makassar, Health Office Section Head of Makassar, Makassar District Health Communication Forum Chairperson, Section Head of Community Empowerment and Welfare (PMK) of Mamajang District, Section Head of Community Empowerment and Welfare (PMK) of Mariso District, Section Head of Community Empowerment and Welfare (PMK) of Panakkukang District, Section Head of Community Empowerment and Welfare (PMK) of Rappocini District, Section Head of Community Empowerment and Welfare (PMK) of Tallo District, Section Head of Community Empowerment and Welfare (PMK) of Tamalate District, Section Head of Community Empowerment and Welfare (PMK) of Tamalanrea District, and Section Head of Community Empowerment and Welfare (PMK) of Wajo District.
Data collection was carried out by in-depth interview with the informant. Then, the documentation of the activities was carried out through a document review of various literature and other sources.

Data analysis was performed qualitatively using grounded theory. The grounded approach starts with making research questions while continuing to collect data in the field. After the data are collected then the coding is done.

\section{Results}

\section{Women's involvement}

Based on the results of in-depth interviews (in-depth interviews) regarding the involvement of women, the informant said that women's participation in the implementation of healthy cities in the city of Makassar was very large, active, and participatory. This is shown from the results of in-depth interviews conducted with 13 respondents showing the results that the involvement of women in the implementation of the healthy city program can be seen from the chief coordinator in 9 of the 15 districts in the city of Makassar which are women. In addition, based on the results of direct observations made it is known that the person directly responsible for the healthy city program in Makassar is the head of the Makassar city health office, in this case, women. Furthermore, $70 \%$ of those involved in implementing healthy cities at the village and household level are women.

\section{Politic commitment}

Based on the results of in-depth interviews (in-depth interviews), regarding political commitment informants said that the political commitment of the city government is seen from various existing regional regulations that support the implementation of the healthy city program in Makassar. Based on direct observation and document review, it has been known that since the implementation of a healthy city in Makassar, there have been various regulations that were born or updated to adjust to the concept of a healthy city program that has been implemented by the government. In addition, the informant also stated that the political commitment of the Makassar city government is also evident from the many awards that Makassar city has received since the issuance of a national policy on the implementation of a healthy city in Indonesia as well as city government programs that are in line with the concept of healthy cities such as Healthy Hallway, Garden Hallway, Makassar Not Rantasa', LISA (See Trash Take), Sombere' City, and so on. 


\section{Discussion}

An evaluation was carried out on the two impacts of implementing a healthy city in Makassar. The first impact is the impact of women's involvement in the implementation of healthy cities in Makassar, while the second impact evaluated is the impact of implementing healthy cities on political commitments from the Makassar city government. Both of these impacts show good evaluation results, but still need deeper study.

Involvement is an interest or motivational part that is generated by a particular stimulus or situation and is addressed through appearance characteristics. Involvement is seen as a person's relationship to an object based on needs, values, and interests [12]. Meanwhile, according to the WHO [11], the level of involvement is how much participation from the community in the implementation of a program or activity.

The key strategy of the healthy city program is to unite the involvement of various stakeholders from government, the private sector, non-governmental organizations, and all elements of society to focus on urban health issues and to address health-related issues broadly [11]. This makes stakeholder involvement very important. Women and the government are part of stakeholders who also have an important role in implementing healthy cities.

Theinvolvementofwomenintheimplementation of healthy cities in Makassar based on the results of the study was considered to be active and participatory. Based on the guidelines for the healthy city program by the WHO, it is emphasized that women's involvement is very important in the implementation of healthy cities. In general, the level of women's involvement in urban development initiatives tends to reflect the level of women's involvement in other aspects of city life [11].

This is shown from the number of field implementers in implementing healthy cities in Makassar, which are women. At the kecamatan level, all responsible/coordinators in the healthy kecamatan communication forum are women. Women are seen as the prime movers in society. The results of this study are in line with research conducted by the WHO [11] in the city of Dar-es-Salaam, Tanzania, which states that women's participation in the healthy city program in the city is very high. This is indicated by the large number of women workers in government agencies and the private sector who are responsible for implementing healthy cities in Dar-es-Salaam.

The next indicator is political commitment. Political commitment is defined as the commitment of political actors who have political influence in a city, such as the Mayor and Deputy Mayor [13]. Boonekamp et al. [14] described the need for high-level political commitment to the Kota Sehat program to increase the likelihood of program success. Time, cultural change, and goal determination efforts from healthy city coordinators affect the city government and other city organizations that support the implementation of the healthy city program [15], [16], [17].

Based on the results of the study, the political commitment of the Makassar city government toward the implementation of the healthy city program is very good. This is indicated by the existence of various regulations that are considered to support the implementation of the healthy city program in Makassar. In addition, Makassar city has won the highest award in the category of healthy cities at the national level, Swasti Saba Wistara for 4 times in a row, which also shows the high political commitment of the government in creating Makassar city as the best healthy city in Indonesia. The Makassar city government also always participates in various activities related to the healthy city and also supports the work of the healthy city forum in the city of Makassar. This was evidenced by various reports in the media and interviews with the Chairperson of the Makassar Healthy City Forum and the Head of the Socio-Cultural Affairs Section of the Makassar City Bappeda.

The results of this study are in line with research conducted by the WHO [11] in Dar-esSalaam, Tanzania. The results of the study showed that the Mayor of Dar-es-Salaam along with the head of the health department in the city played a very active role in various activities related to healthy cities, by attending meetings that were scheduled on policies and implementation related to healthy cities and also cooperating with healthy city committees in cities.

\section{Conclusion}

However, coordination at the government level is expected to be further improved, because there is still frequent miss communication between several Satuan Kerja Pemerintah Daerah in the implementation of tasks to achieve healthy city indicators.

\section{Recommendation}

The level of involvement is one of the impacts in the implementation of a healthy city consisting of two indicators. An evaluation of the two indicators gave satisfactory results. The involvement of stakeholders in this matter is that women have been quite active and participatory. Besides that, the political commitment of the Makassar city government itself has succeeded in bringing satisfactory results to the development of the city. However, it is recommended for each Satuan Kerja 
Pemerintah Daerah (SKPD) at the city government level to further improve coordination with each other, because there are still overlapping tasks between each SKPD.

\section{References}

1. Moore M, Gould P, Keary BS. Global urbanization and impact on health. Int J Hyg Environ Health. 2003;206(4-5):269-78.

PMid:12971682

2. Lisangki D. Studi tentang kredibilitas walikota samarinda dalam meningkatkan partisipasi masyarakat untuk mewujudkan kota hijau, bersih dan sehat di Kecamatan Samarinda Hilir. E J Komunikasi Univ Mulawarman. 2015;3:51-62. https://doi. org/10.25273/gulawentah.v1i2.1035

3. Palutturi S. Healthy Cities: Konsep Global, Implementasi Lokal untuk Indonesia. Yogyakarta: Pustaka Pelajar; 2017.

4. Soedirham O. Kota Sehat sebagai bentuk sustainable communities best practice. Kesmas Natl Public Health J. 2012;7(2):51-5. https://doi.org/10.21109/kesmas.v7i2.9

5. Mulasari SA. Membangun Kota Sehat (healthy city) menuju Indonesia sehat berkemajuan. J Pemberdayaan. 2019;2(2):18794. https://doi.org/10.12928/jp.v2i2.419

6. Dinkes Kota Makassar. Penyelenggaraan Kota Sehat di Makassar. Makassar: Dinas Kesehatan Kota Makassar; 2018. https://doi.org/10.32382/medkes.v11i2.236

7. Iskandar DT, Sumartono S, Domai T. Evaluasi dampak pelaksanaan program pembinaan dan pengembangan industri kecil dan menengah di kabupaten Ponorogo. J Borneo Adm. 2017;13(1):21-40. https://doi.org/10.24258/jba.v13i1.273

8. Baum F. Researching public health: Behind the qualitative methodological debate. Soc Sci Med. 1995;40(4):459-68. https://doi.org/10.1016/0277-9536(94)e0103-y

PMid:7725120

9. Werna E, Harpham T. The evaluation of healthy city projects in developing countries. Habitat Int. 1995;19(4):629-41. https://doi. org/10.1016/0197-3975(95)00023-9

10. Tahalea SN, Suwitri S, Rostyaningsih D. Evaluasi dampak kebijakan penyelenggaraan pelayanan terpadu satu pintu di badan pelayanan perizinan terpadu kota Semarang. J Public Pol Manage Rev. 2015;4(3):387-99. https://doi.org/10.32528/ politico.v18i1.1377

11. World Health Organization. Healthy Cities in Action: An Evaluation. Geneva: World Health Organization; 2000.

12. Japarianto E, Sugiharto S. Pengaruh shopping life style dan fashion involvement terhadap impulse buying behavior masyarakat high income Surabaya. J Manajemen Pemasaran. 2012;6(1):32-41. https://doi.org/10.9744/pemasaran.6.1.32-41

13. Burton $S$. Evaluation healthy city projects: Stakeholder analysis of two projects in Bangladesh. Environ Urban. 1999:11(1):4152. https://doi.org/10.1630/095624799101284850

14. Boonekamp GM, Colomer C, Thomas A, Nunez A. Healthy cities evaluation: The coordinators's perspective. Health Promot Int. 1999;14(2):103-10. https://doi.org/10.1093/heapro/14.2.103

15. Clark DK. The city governments's role in community health improvement. Public Health Rep. 2000;115(2-3):216-21. PMid:10968757

16. Kayame R, Mallongi A. Relationships between smoking habits and the hypertension occurrence among the adults of communities in paniai regency, Papua Indonesia. Indian J Public Health Res Dev. 2018;9(1):332-6. https://doi. org/10.5958/0976-5506.2018.00061.x

17. Birawida $A B$, Selomo $M$, Mallongi $A$. Potential hazards from hygiene, sanitation and bacterium of refill drinking water at Barrang Lompo Island (water and food safety perspective) IOP Conf Ser. 2018;157(1):012034. https://doi. org/10.1088/1755-1315/157/1/012034 